\title{
A Comparative Postcolonial Analysis: The Conscript (1950) and The Glass Palace (2000)
}

\section{OPEN ACCESS}

Manuscript ID:

ENG-2020-08032449

Volume: 8

Issue: 3

Month: June

Year: 2020

P-ISSN: 2320-2645

E-ISSN: 2582-3531

Received: 06.04.2020

Accepted: 19.05.2020

Published: 02.06.2020

Citation:

Reka, Mahder. “A

Comparative Postcolonial

Analysis: The Conscript (1950) and The Glass

Palace (2000)." Shanlax

International Journal of English, vol. 8, no. 3, 2020, pp. 1-12.

DOI:

https://doi.org/10.34293/

english.v8i3.2449

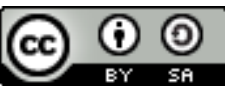

This work is licensed under a Creative

Commons Attribution-

ShareAlike 4.0

International License

\author{
Mahder Reka \\ Assistant Lecturer, Department of English, College of Education \\ Eritrea Institute of Technology, Eritrea, Horn of Africa \\ Part II MA English, Goa University, Goa, India \\ D https://orcid.org/0000-0002-3158-8703
}

\begin{abstract}
The present comparative postcolonial analysis aims at drawing thematic parallels between two postcolonial novels: The Conscript (1950) by Ghebresus Hailu (Eritrea, Horn of Africa) and The Glass Palace(2000) by Amitav Ghosh, India. Though the novels are productions of two different geographical space, cultural and colonial experience, they have stark similarities. In The Conscript Hailu paints a picture of his colonized country men under Italian masters similarly, Ghosh in The Glass Palace attempts to delineate the life of Indo-Burmese people under the British Empire. Although a lot of research has been carried out on Anglophone and Francophone colonial literature, there hardly exists any analysis of Italian colonial literature. In this regard comparative analysis of The Conscript (a novel written in Tigrigna, a language spoken in Eritrea, East Africa and translated into English by Ghirmay Negash, a professor in Ohio University) and The Glass Palace, I believe will provide additional knowledge concerning Italian colonial experience vis$\grave{a}$-vis wide existing Anglophone and Francophone literature. The thematic commonalities drawn between The Conscript and The Glass Palace in this paper are native role and complicity, racism and interiorization, dislocation, colonial order, traumatic effects of colonialism in the colonized, decolonization strategies, and anticolonial consciousness. I will explore and analyze the relations of the two novels based on afore mentioned aspects. Then following the discussion I will conclude by revisiting some general points concerning the texts. This paper mainly frames its arguments on theoretical frameworks of Rene Wellek, Robert Young, Edward Said, and Franz Fanon about notions of comparative literature, resistance, and representation, exploitation, and interiorization. Keywords: Postcolonialism, Comparative Study, Native Complicity, Exploitation and Inferiorization, Awakeningand Anticolonial Consciousness.
\end{abstract}

\section{Introduction}

Literature in the immediate aftermath of anticolonial struggles depicts, among other things, the problems of colonialism. The authors of imaginative literature thematized issues of colonialism and captured the socio-cultural impact of colonialism in native and non-Western societies. An important area for postcolonial writers was how native societies reacted to the Western cultural presence. Therefore, postcolonial novels, in a way, were case studies of cultural nationalism, native identity, and anti-colonial resistance. Postcolonial obsession is part and parcel of the principal goal of decolonization. The postcolonial texts that have been frequently discussed are predominantly from Anglophone and Francophone literature. However, previous studies in this area have reported texts from other colonized people who have been under other European imperial powers are not substantially different. Hence V.G. Kiernan opines empires 'imitate one other' (qt. in Said 8).

Texts produced in non-European societies after Said's two ground breaking books Orientalism (1978) and Culture and Imperialism (1993) are considered in a new light as means of resistance to colonialism and attempt by the natives to represent and rewrite native history. 
Though Said's Orientalism has not used the term postcolonial, it changed the focus of academic attention from the dominant mainstream western narrative to the emerging intercultural discourse of the 'other.' The postcolonial theory had existed long before that particular name was used to describe it. Colonized people have a cause to reflect on and express the tension that ensued out of a problematic relationship with the colonizer from the time colonizers set foot on their lands. The postcolonial theory brings Eastern cultures, literature, and the vast scholarship of the other half of the globe from the margins to the centers of learning and teaching. What post-colonial literature have in common beyond their spatial and distinctive regional characteristics is that they emerged out of the experience of colonization and asserted themselves by foregrounding the tension of asymmetrical power relations and by emphasizing their differences from the assumptions of the imperial center. This is what makes them distinctively postcolonial (Ashcroft et al., 2).

The two novels to be compared here are certainly texts written with motives above. They share the fictionalized native view of the history of the community under colonization, struggle for freedom, and ironically the native's naïve collaboration with the colonizers in expanding the empires. The Conscript deals with a group of Eritrean conscript soldiers who were sent from the colony - Eritrea to fight for Italy's imperial project in Libya, then Italy's third colony in Africa. The vast majority of the Italian soldiers In The Conscript were Eritreans, who are taken to Libya to fight Arabs and consolidate the Italian base in Libya. Similarly, The Glace Palace depicts the huge amount of Indian soldiers who make the British army and their contribution to controlling Burma and other parts of Southeast Asia. The enmity between Burmese and Indian soldiers in The Glace Palace and the hostility between Eritrean soldiers in Libya and the Libyans in The Conscript is also a vivid parallel between the novels. This disparity is also intensified by the colonizer's divisive propaganda. 'Colonialism is separatist and regionalist.' 'Colonialism is not merely content to note the existence of tribes; it reinforces and differentiates them' (Fanon 51). The violence and psychological crisis inflicted on the characters in both the novels, nevertheless, changes the awareness of the protagonists who initially believed and favored the colonizers. Consequently, they become conscious of their status and decide to fight for their freedom.

\section{Postcolonial Comparative}

Postcolonial comparative involves the most radical form of comparative literature: it compares the hitherto incomparable (Young 687). It resists how its literature has been compartmentalized - for example, the carving of the Caribbean literature into forms of English, American, French and Spanish literature, as writers on different islands had relations only with the metropolitan center. The radical move has been to compare the uncompared, literature considered incomparable, a dimension that has been developed forcefully in minority literature. Postcolonialism is not merely the new comparative literature in criticism; it only involves a new form of comparative literature. Thus post colonial literature is inherently comparative, intrinsically more comparative than other literature because it is defined by its comparative.

Young argues post-colonial writers have no choice: that work was done by the violent historical imposition of colonialism, which forced postcolonial society and its literature into the comparison in the first place. Edward Said, in his Culture and Imperialism, assume that literary texts and cultural productions are manifestations of power and authority. In his book, Said reinterprets the European writing of the nineteenth and twentieth centuries in Africa, India, and some parts of the Far East, Australia and the Caribbean and presents it as constitutive of the ideological discourse of European domination and representation of this lands and peoples during the modern Western imperialist periods. By the same token texts produced by natives of the colonized world written during and after the colonial period are means of resistance and representation of their self against subverted history and exploitation by the empires. The Conscript by Ghebresus Hailu and The Glass Palace by Amitav Ghosh is unified by the reality of the colonial past. 
1. Native Soldiers' Role and Complicity in the Empires

Italy has conscripted around 130,000 Eritrean Soldiers against the Libyan nationalist forces during its invasion of Libya. Set against this historical backdrop, The Conscript depicts these soldiers' staggering journey. The novelist questions Habesha soldiers' heroic assumption and celebration for their participation in Italy's army. Tuquabo, the protagonist of the novel, joined the Italian army with profound excitement and enthusiasm. Colonial criticism is juxtaposed with native complicity in the novel. At the start of the novel, Tuquabo decides to join the army and departs to Italy despite being the only son of the family. His family objects him: " Why do you wish to fight for a foreigner? What use is it for you and your people to arm yourselves and fight overseas?' (TC 8). These utterances display the writer's explicit indictment of the colonized people for their naïve collaboration in the colonizer's scheme.

Hailu describes the time of war in Libya as a time 'deemed fitting for the people of Habesha/Eritrea to be willing to spill their blood in this war' The youth were singing, ' $\mathrm{He}$ is a woman who refuses to go to Libya' (TC 7). This irrational chauvinistic principle has driven many of the youth of the day to get conscripted and to fight other wars in Libya. The Habesha people grew up hearing these boastful views and decide to go to Libya to fight like a hero and gain fame. The novel records the Habesha prayers, 'Lord, don't let us be dormant, please bring us war' (TC 7). It is this warring eagerness that exists in the society which compelled Tuquabo to be a soldier.

Hailu, while painting a devastating portrait of European /Italian colonialism and exposing the operations of foreign domination, also alludes to the obstacles of liberation. He holds the colonized Eritreans themselves as partly responsible for their exploitation. He criticizes the pro-war mindset of the Eritrean youth and their chiefs who pray for war because 'the exercise might help them trim their fattened bodies' (TC 7). The Eritrean youth brand of masculinity, their passive acquiescence to the Italian colonization, and the international export of the youth as mercenaries are, however, confronted by the elders as demonstrated by Tuquabo's parents.
However, Tuquabo realizes and regrets his decision when the ship takes off from the port of Massawa on the Red Sea coast. He states, 'leave your family and country behind/ for someone else's expanse' (TC 15). Hailu precautions against the misrecognition of the enemy through the Habesha conscript's inner voice 'Beware Habesha, the Arabs are not your enemies. Will you be able to recognize your enemy?' (TC 21). However, the starkest critique of the writer against the conscripts is encapsulated in verse:

He who fights on a foreign soil another man's war Not for his family or his country honor

And when he lies dying, hit by a deadly blow.

From an angry fireman

But cannot say, 'Oh! My beloved country

Here is the life you gave me, and I come back to you.'

Dies twice, reduced to eternal wretchedness.

(TC 23)

A poem originally written by Leopardi, a famous Italian poet, Hailu, claims would have been the most fitting for the Habesha conscripts.

Hailu reprimands the contentment of Habesha soldiers display when selected to serve the white man. They consider themselves privileged to perform petty activities for the Italian soldiers, such as: making a bed, cooking food, lighting cigarette, or preparing his sword and weapons. The novelist describes the Habesha servitude 'thought he had reached seven skies higher than his colleagues' (TC 26). Hailu chastises and compares this act with 'one who follows a mule and feels full by smelling its dung' (TC 26).

In the same vein, the British Indian Army in The Glass Palace comprises a vast majority of Indian soldiers. These are conscripts who are contented to be members of The Empire. When the British invaded Burma in 1885, out of some ten thousand soldiers, the great majority - 'about two-thirds were Indian sepoys'(TGP 26). It is also mentioned in the novel that these were loyal soldiers to the British, and they stood steadfastly in 1857 uprising in suppressing their people. The British Empire was using these soldiers to expand and defend its empire and fight its war throughout the novel. Saya John, in the novel, recalls, 'In Singapore, as a young man, I worked for 
a time as a hospital orderly. The patients were mainly sepoys like these - Indians back from fighting wars for their English masters' (TGP 29). He then wonders, 'what makes you fight,' 'when you should be planting your fields at home?' 'Money,' (TGP 29) they would say though what they earned was few annas a day. Ghosh, like Haile, explicitly denounces the Indian Soldiers for allowing themselves, 'To be used to fight other people's wars with so little profit for themselves' (TGP 30). He terms the soldier's willingness to kill for their masters as 'an innocent evil.' Ghosh accuses the soldiers of a lack of awareness and naivety. For example, when Arjun criticizes generations of his forefathers for helping the British colonize many parts of South East Asia, Hardy points to their illiteracy.

Uma, the collector's wife, is a fierce critic of colonialism in the novel. She is also notable for her role as an inspirer of the Indian independence movement. Her remarks and dialogues with Arjun, Rajkumar, Mrs. Dutta, and others reveal the core themes of the novel. For instance, she challenges and forces Arjun to reflect on his status. Arjun, who is an ardent believer of the benevolence of the empire, is forced by Uma to reflect on his desperate state, 'Arjun - you are not in charge of what you do; you are a toy, a manufactured thing, a weapon in someone else's hands. Your mind doesn't inhabit your body' (TGP, 376). Rajkumar is another character in the novel that Uma holds responsible for the tragedy of Indian plantation workers in Burma. Uma blames Raj, 'Did you ever think of the consequences when you were transporting people here? What you and your kind have done is far worse than the worst deeds of the Europeans'(TGP 376).

Indian soldiers were also used by the British to root out the rebellions and mutinies. During the riots in Burma, the British suppressed and killed many people. 'In the city jail, a mutiny erupted among the prisoners and was suppressed at the cost of many lives'(TGP 246). Uma comments: 'I can't believe what I've seen here - the same old story, Indians being made to kill for the Empire, fighting people who should be their friends ...' (TGP 247). The British Indian Army was also engaged in defending the British overseas territories during the Second World War. As part of this, some were serving in
North Africa, some in Eritrea (East Africa), Malaya, Hongkong and Singapore.

Though many of the soldiers joined the army for money, several of them were naïve about British intentions. Uma, for example, meets Sikh Giani in Calfornia, a former British Indian soldier, and enquires him why he was being used to conquer others like himself. He responds, they believed they were freeing those people; ' That is what they said - that we were going to set those people free from their bad kings or their evils customs' (TGP 224). The rhetoric of 'white man's burden' beguiled them. Many of the characters, such as the Collecter, Hardy, Arjun, and Rajkumar, have succumbed to this deceptive trap and were mentally colonized. Ghosh debunks the soldiers fighting for their British masters from neither enmity nor anger but in blind submission to orders from superiors without any protest.

The novel sketches how the colonial ideology has succeeded in indoctrinating many people and their fascination for the English system of thought and the English way of life. For many of them, modernity is synonymous with being and feeling like English. For instance, Beni Prasad, the Collector, backs British ousting of king Thebaw and argues for his seclusion. When Uma describes this move as monstrous, the Collector defends, 'It's merely judicious.' He adds, 'If it weren't for the British, the Burmese would probably have risen against these Indian businessmen and driven them out like a sheep'(TGP 136).

Hardy and Arjun acquiesced to be British Indian soldiers and justify their presence and draw pride from their membership. Their relationship with the British was the source of their pride and prestige. The narrator also tells Hardy's life dream was to be called 'Sahib' by his father's colleagues. Both of them are tremendously excited about being the first Indian officers in the 1/1 Jats. Similarly, as a result of the proximity with the westerners, Arjun exclaims, 'We know how the mind of the westerners works. Only when every Indian is like us will the country become truly modern' (TGP 280). Arjun is berated by the Burmese student activists when he tried to justify the Indian soldier's presence in Burmese soil. When he tells them that they are not occupants, rather they are there to defend them, they react 'From whom are you 
defending us? From ourselves? From other Indians? It's your masters from whom the country needs to be defended' (TGP 288). Hence the Burmese disparage these Indian soldiers as slaves who catch other slaves for their masters. At times they were also belittled as Klang - earliest chained Indian workers who were brought to Malaya.

\section{Colonial Exploitation and Inferiorization}

Colonialism has always been malicious and devastating for the colonial subjects. Nevertheless, imperial texts tend to legitimize and justify it in the guise of bringing civilization to the colonies. However, postcolonial writers attempt to subvert this colonial rhetoric. Michael Parker and Roger Starkey have observed, 'European colonists and earlier generations of European writers had regarded vast regions of the world merely blank spaces, lands 'without narrative' waiting to be mapped, mined, written into existence' (Parker and Starkey 3). Imperialism, by its very nature and drive, aims at ideological control of the natives and the material resource in their lands. In achieving this goal, the colonizers consider the consequence it entails on the colonized as only collateral. In the conscript, Hailu depicts this ordeal, "They marched on and on in the desert for seven days - hungry, thirsty and suffering from the blistering heat and sand storms' (TC 27). However, all the Italian soldiers were on mules.

The incursion of Burma by the British is motivated by a need for resources. The empire's ravenousness is demonstrated in Burma. As soon they occupy Burma, 'Resources were being exploited with an energy and efficiency hitherto undreamt of " (TGP 66). The Queen of Burma, after she has been exiled to Ratnagiri, warns some of the visitors about the catastrophe and exploitation of the British under the disguise of developing Burma. She remarks:

This is what they have done to us; this is what they will do to all Burma. They took our kingdom, promising roads, and railways and ports, but mark my words. This is how it will end. In a few decades, the wealth will be goneall the gems, the timber, and the oil... we were the first to be imprisoned in the name of their progress; millions more will follow. (TGP 88)

On the plantations, the value of coolies was lesser than the value of the elephants. They were constantly subject to racist abuse from their white and Eurasian overseers. That's what Saya John warns to Rajkumar: 'The big English companies could destroy you, make you a laughing stock in Rangoon. You could be driven out of business' (TGP, 130). Later in the novel, through the character of Dinu, Ghosh severely criticizes fascist ideas. He gives a long speech about the nature of the forces that function against human freedom and dignity. He tells Uma, “Don't imagine for a moment that India and Burma will be better off if the British are defeated... The German's plan is simply to take over the Empire and rule in their place... and think of what'll happen in Asia...The Japanese are already aspiring to an Empire, like the Nazis and Fascists" (TGP 293).

Hence both the novels reveal the Machiavellian principles of the colonizers to quench their insatiable greed and psychology of imperialism.

\section{Inferiorization}

In his article Racism and Culture (1955), Fanon maintains, 'It is not possible to enslave men without logically making them inferior through and through' (Fanon 50). Similarly, Paul Nursey notes, the debasement of national culture, history, and society is the other half of the ideology of domination that accompanies colonialism (Nursey 137).

In Nandy's words, the drive for mastery over men is not only a by-product of a flawed political economy but also a world view that beliefs in the absolute superiority of the human over a subhuman and nonhuman. In these novels, the natives are consciously humiliated and belittled on the bases of their color and identity by the colonizers to render them passive subjugation. Hailu's novel The Conscript is startling for its lucid anticolonial stance, and its rejection of the afore mentioned assumptions. The novel scrutinizes the ideological relationship between the Italians as colonizers and Libyans and Eritreans as colonized subjects. The Italians manifest themself assumed superiority against Arabs and Habesha soldiers on several occasions and in various forms. Like Fanon and Cesaire, Hailu highlights the dehumanization at the core of colonial domination. He bestializes carriages of the empire, 'the black trucks .... roared like starving lions, hungry to 
swallow the Habesha people in their beastly bellies' (TC 12). The Italians regard the Habesha/Eritrean soldiers as donkeys and dogs.

Hailu foregrounds the stereotypes Italians hold against the Arabs. However, these are unfounded myths intended by Italians to divide and rule. They enact such tactics not only through physical force but also through social engineering and propaganda. He declares to have read several stereotypes from an Italian book. In the book, the Arabs are stereotyped as untrustworthy, incapable of fighting a war, and indolent. But a closer reading of the book reveals that this was a subtle form of the colonial conspiracy of interiorization. As the narrator points out, it is the Italians who are responsible for spreading these accounts of Arab 'laziness,' which are falsified by their bold spirit as soldiers in defending their country, Libya, against colonization. The Arab bravery that Tuquabo observes firsthand exposes the fictitiousness of colonial representation and fallacy. It is worth mentioning here a story the writer tells about the Arab/Libyan indolence that he claims to have read from the Italian book.

The story goes, there once was a man whose wife was about to deliver a baby. The man needed a bed and went to see the carpenter to procure it. The carpenter took the money and made an appointment for the man. When the man went to take his bed, it wasn't ready. He visited the carpenter twice and thrice but to no avail. Then the man's wife gave birth to a baby boy. The boy grew up and got married. His wife was about to have a child. The boy then approached his father and asked for money to buy a bed for the expected child. His father then recalled the money he paid for the carpenter twenty years back and suggested they visit the carpenter and get the bed if it is ready. When they inquired the carpenter, he vehemently, replied, 'Why are you giving me such trouble, I don't like to do things in a hurry. And now, if you don't want me to make you a bed, here is your money, take it' (TC 33). He had failed to do a job given to him for twenty-one years'. This and other related stories in the book are designed by the colonizers to humiliate the subjects and bring out the interiorization. Another instance of stereotyping and interiorizing the colonized soldiers is demonstrated by the words of the Italian commander before they embark on war. He exclaims:

O black Eritrean Ascari! Those whom you are now going to fight against are but a bunch of shepherds. You may perhaps be frightened because they are whites. However, they are not like us. They do not possess guns, nor do they have ample bullets. We alone are the brave whites; we Italians your masters. (TC 27)

According to the Italians, though the Arabs are whites, the fact that they are not Europeans makes them inferior. It is absurd to presume greatness based on the color of skin. Similarly, the commander reminds the Habesha soldiers that they should feel gratified and privileged to fight under the Italian banner. Hence he restates, 'you should fight well for us' (TC 27). He then forces them to repeat after him as he shouts, 'Viva L'Italia; viva Emanuele, our king!' (TC 27).

Stereotyping and interiorization of the native Indians by the British are also flagrant in The Glass Palace. The white race's inherent superiority and the native's inferiority manifests in different forms. For instance, in the novel, the idea of race and color is noticeable in the British Indian Army. Many restaurants, clubs, and beaches have signs in their doors that read 'No Asiatics allowed' (TGP 345). Similarly, Arjun recounts a story to Dinu about English colonel, who holds the view that 'Making officers out of Indians would destroy the army; everyone would be at each other's throats, and the whole thing would fall apart'(TGP 283). Moreover, the British procedure of recruiting people in the army and plantations is founded on divisive and stereotypical notions. The recruits for the army were selected from the so-called 'martial races,' while the indentured labor for the plantations was recruited, often forcibly, from the 'fallen' races - Tamils.

The most explicit and bigoted remarks, however, are uttered by the British officer, Colonel Buckland. In his attempt to validate the British presence to Arjun, he states:

The truth is that there's only one reason why England holds any more - and that is out of a sense of obligation. I know this may be hard for you to believe, but it's true.

There is a feeling.... we can't leave a mess behind. And you know as well as I do that if 
we were to pack our bags now, then you chaps would be at each other's throats in no time even you and your friend Hardy, what with him being a Sikh and you a Hindu, a Punjabi and a Bengali... (TGP 417)

Thus as can be inferred from the above instances, the novels encapsulate interiorizing and stereotyping of the natives based on color as an integral part of colonization.

\section{Psychological crisis and Trauma of Characters}

Colonialism not only drains the physical resources of a colony, but also inflicts psychological crisis on society under its control. It thwarts the aspirations and lives of colonized. Fanon believes colonialism systematically negates the 'other' and denies any human attributes to them. The lives of the characters as victims in both novels attest to the perverting powers of colonialism.

In The Conscript, Tuquabo's mother, Tekla, had six children. However, five children couldn't make it through infancy. Hence Tekea named the son Tuquabo - God's gift. When Tuquabo left for the Libyan war, Tekea was haunted by the concerns that her son would die in the war, 'Would he ever come back?'(TC 6). She expresses her dread of Italians, 'He was now in the hands of the heartless Italians, and there was no way they could get him back' (TC 8).

Tuquabo being the only son for the family, and taken as a conscript, has caused profound distress to the family. They had to wait anxiously for his return. Tekla was having nightmares and was calling her son's name in her sleep. There were times for her, 'The dream would seem so true that she would stretch out her arms to hug him, before suddenly walking from her slumber'(TC 50). During the harvest season, she bemoans Tuquabo's absence, 'What good is it if there is no one to eat? Time went by, and a rumor went around about the return of the conscripts. Tekla couldn't bear the news. The novel delineates the pathetic sight of the mother:

It gave life briefly to her weary heart, pounding with joy and excitement (and she was old) made an artery rapture and stopped beating altogether. In a blink of a moment, she passed away thus, calling her son's name. Her husband fell into the deepest sorrow imaginable. Besides missing his son, he had also lost his wife. (TC 51)

As has been detailed above, colonialism has deprived Tekea of her only son, the gift, and the only hope in life, thereby exposing her to a mental crisis that claimed her life eventually. The novel, in fact, clearly states that the story of this family is the story of many Habesha/Eritrean families whose lives were distorted by the colonial experience.

In the novel, the conscripts are treated as a group of characters. After a series of clashes, notwithstanding their bravery and some small successes, the Eritrean conscripts are soundly beaten, and their unit is in total disarray. Some die fighting; a few perish of thirst and hunger; others go missing. The novel describes the chaos created by the war, and the tormented central character, Tuquabo, remembers events and reflects on his involvement in the war as a conscript soldier. Tuquabo's criticism takes the form of specific grievances about the conduct of the colonial army commanders. The psychologically demoralized, physically exhausted conscripts traverse through the desert, sinking towards death for want of a 'drop of water to wet their lips.' At the same time, the Italian officer in charge is depicted guarding his water before he eventually runs away, leaving his troops behind to their lot (TC 45-48). This section is fittingly entitled 'Thirst of Death,' and Tuquabo's rendering of the horror is graphic:

Whenever the soldiers heard the sound of sprinkling water, their hearts jumped with it. It was exactly like watching a dog which, while one is eating, its eyes raise and lower following the movement of one's hand. They were after all (like) dogs if you compare them with the Italians. Dogs fare better; they at least eat the left overs of their master. (TC 46)

In The Glass Palace, the soldiers and their close family members are immediate victims of colonialism. The trauma is vicious in the families who live through soldiering. For example, Kishan Singh is one of the victims of such families. Singh's father was a British Indian soldier who travels the world - Malaya, Burma, China, and East Africa. After being wounded severely, he had to barter away the family land. Nevertheless, he eventually dies. Then, Kishan Singh was forced to join the army by quitting studies at the age of fourteen. When 
Bela inquires Singh about the life of women of such soldiers in his village, he responds, 'They are soldiers too. From the time they are little, they begin to learn what it means to be widowed early; to bring up children without their men; to spend their lives with husbands who are maimed and crippled' (TGP 290). Similarly, Arjun's exhaustion and desperation with the empire after fighting several wars is revealed by the end of the novel. Dinu accuses him of joining the army in his own will. When she pointed to his hopeless condition, he laments his inner dilemma and pain, 'We rebelled against an Empire that has shaped everything in our lives; colored everything in the world as we know it. It is a huge indelible stain that has tainted all of us. We cannot destroy it without destroying ourselves' (TGP, 518). There are also cases of British Indian Soldiers in the novel who took their own lives out of frustration of notorious evils of the Empire. For instance, an Indian soldier had inexplicably shot an officer and then committed suicide at Singapore's Tyersall Park Camp.

War and colonial invasions play a vital role in separating as well as reuniting major characters in the novel. Some are killed during the Second World War, while others survive with a haunting nightmare and memory of their lost friends and relations. One of the shaking and poignant incidents that the novel depicts about imperialism is the death of old Saya John out of fatigue for traveling long in quest of safety. Thus war, communal violence, and merciless imperial onslaught bring down disastrous impacts and unwanted death in the lives of ordinary individuals, creating irreparable loss, suffering, and pain. This torture left indelible stigma in the history and collective memory of a nation or a society. It also due to war between the British and Japanese that Rajkumar was left impoverished and dispossessed of his fortune and wealth in Burma.

The royal family was also humiliated by British imperialism and brought down to the level of commoners. They are removed from their kingdom, stripped of their material wealth, and held hostage in a foreign city. They are subjected to many scandals. For instance, one of the princesses runs away with a suitor, and another married a man below her status. Gradually their travails seem similar to those of ordinary families. When the Collector came to see the Queen about the pregnancy of the first princess as a scandal, she furiously expresses her anguish to him, stating:

There is no scandal in what my daughter has done. The scandal lies in what you have done to us, in the circumstances to which you have reduced us, in our very presence here. What did my daughters ever do, Collector - sahib, that they should have to stay their life in prison? Did they commit a crime? Were they tried or sentenced? We have heard so many lectures from you and your colleagues on the subject of the barbarity of the kings of Burma and the humanity of the Angrez; we were tyrants you said, enemies of freedom, murderers. The English alone understand liberty, we were told; ..... If that so, why has king Thebaw never been brought to trial?... Is it a crime to defend your country against an invader? Would the English do not do the same? (TGP 150)

As illustrated in the above words of the Queen, the Royal Family was made to endure profound humiliation. King Thebaw suffered a heart attack and died ten days later of grief and frustration when Second Princess has eloped with a commoner and refused the king's request to return.

Colonialism displaces and disintegrates society. By disconnecting family members, it enforces on them a sense of being socially or culturally 'out of place.' Many families and individuals in both the novels under discussion are victims of forced dislocation. There is a story of a woman in The Conscript, who left her homeland and came with her brother to Asmara city after a war. They were the only ones left in the family. However, her brother joined the conscripts and died in the war. She was torn and heartbroken in distress when she went to the train station to receive the returning conscripts and found out her brother has died. She moans and groans in anguish :

What would my people say to me, think of me? Oh, brother, we left our homeland together -- am destined to return alone? If they asked me where he fell, I wouldn't be able to tell. If they asked me where he was buried, I wouldn't ever know where he was. What would they say to me? I left my home country with nobody to support me except you, my 
brother. Now I don't know where to go. (TC 54)

The shriek of the woman pierced the hearts of all people around. Nevertheless, the novelist affirms, this story was not extraordinary as it happens each time conscripts arrive at the train station from the war for several years.

Several characters are uprooted and displaced in The Glass Palace as well as a consequence of war and expansion. The British have dislocated King Thebaw and Queen Supayalat and exiled them to Ratnagiri (India) along with their attendants after they seized Burma. In the novel, the Anglo-Japanese war forced people to leave their homeland. Rajkumar, Dolly, Saya John, and Uma are the individual characters whose lives are disrupted by the war. The Bengali immigrant Rajkumar is alienated forever from his homeland India. Despite his long stay in Burma, he views the country as a place where no one is related to him, where he knows so little, where life seems so tentative and spare. After he made his fortune through trading rubber and teak in Burma, he went bankrupt during World War Two and was forced to seek shelter in Calcutta. The other character who was forced into dislocation in the novel is Dolly. She left Burma at an early age as an entourage to the royal family when the British invaded Mandalay (capital of Burma) in 1885. She feels that the Burma she has left behind is lost to her forever, and this displacement creates in her crises of identity. She confesses to Uma Dey:

If I went to Burma now, I would be a foreignerthey would call me a koala like they do Indiansa trespasser, an outsider from across the sea. I'd find that very hard, I think. I'd never been able to rid myself of the idea that I would have to leave again one day just I had to before. You would understand if you knew what it was like when we left. (TGP 113)

As a colonized subject, Dolly, like Rajkumar, suffers from a sense of imaginary homeland in India. After spending twenty years in exile in India, she leaves for Burma with Rajkumar.

\section{Realization, Awakening, and Resistance}

Many postcolonial texts are not only critical responses against colonizers but also meant to inform and educate their fellow men in resisting the premises of European racial and cultural superiority and colonial oppression. The writers as intellectuals ally themselves with the oppressed; hence they have 'ethical and social commitment' incumbent on them as in Said's words. Hailu's The Conscript (1950), as a text which was written at a time when colonialism was rife, takes a bold step in disclosing the atrocities of imperialism and juxtaposes it with the social consciousness of exploitation. Thus he dutifully assumes a historical role or to use Frantz Fanon's well-known notion 'generational mission.'

As Postcolonial and historical novels, The Conscript and The Glass Palace depict the gradual realization and anti-imperialist consciousness. The initial naiveté and complicity of the colonized thus give way to new awareness. The conscripts' disillusionment with the Italian colonialism and antiwar sentiment lead them to a vital understanding of their status. The Italians dehumanizing treatment and abusive racial language changed the conscripts. They acknowledge their wrong involvement in the empire. For instance, when the conscripts witnessed the Arabs fight for their barren land, they remorse, 'A curse is upon us! We didn't do anything when the Italians came to take out fertile land. Not only that, but we also lead the Italians like the blind... and allowed them to enter our homeland' (TC 41). Similarly, on several occasions in the novel, the soldiers' self-reproach is evident in the utterances such as 'fighting another man's war' or dying for 'another man's cause' or 'instruments for oppressing the other.'

Tuquabo, the protagonist, after experiencing the brutality and subhuman treatment of Italian officials who brand them as 'children,' 'dogs,' and 'donkeys' returns home to find that his mother is dead. He then condemns colonialism. His denouncement is expressed in the form of dirge, which is a symbol of all the conscripts' physical and psychological exhaustion with colonialism. His dirge reads:

Going to a distant land,

Not for the honor of my homeland

Leaving my family behind,

In agony and tears, for two years.

And Knowing I killed my mother to follow my vanity.

Here I return, dragging my feet... 


\section{Farewell to arms}

I am done with Italy and its tribulations

That robbed me off my land and parents

I am done with conscription and Italian medals

Farewell to arms! (TC 57)

As the novel ends, Tuquabo is seen condemning the war in categorical terms. Hence he understands deeply the folly of his engagement in an imperialist enterprise. Thus, he realizes and rethinks what it meant for him to fight for Italian colonialism.

The vastness The Glass Palace enabled Ghosh to fully depict soldiers and society's realization of their status and build the Indian anticolonial consciousness. In Ghosh's words, 'colonialism's difficulty' is 'freedom's opportunity' (TGP 306); hence anticolonial sentiments gradually incepted within and outside India. The Indian Diaspora and former soldiers, in the USA and Canada, and the huge Sikh immigrants turned into dedicated enemies of the empire after realizing the status of India in comparison to the life in the west. This has coincided with the inception of the Indian Independence League. Pamphlets encouraging dissent against the empire started circulating secretly. Arjun once found a dropped pamphlet that reads, 'Why should India, in the name of freedom, come to the defense of this Satanic Empire which is itself the greatest menace to liberty that the world has ever known'(TGP 292).

The Indian Independence League was instrumental in raising awareness. During the Anglo Japanese War, for example, they wrote a pamphlet to the British Indian Soldiers. The pamphlet that is picked by, Kishan Singh, reads: 'Brothers, ask yourselves what you are fighting for and why you are here; do you wish to sacrifice your lives for an empire that has kept your country in slavery for two hundred years?'(TGP 391)

Uma Dey represents and epitomizes the anticolonial nationalist consciousness. Ghosh draws a sharp line between people caught in the Anglicized shell and those trying to see through the hypocrisy of their master's much-flaunted honor and good intentions towards the colonized people. Unlike her husband, Beni Prasad, the Collector who delves into the westernized way of living, Uma Dey, is critical about the wily nature of the British rule pitting against the Burmese. She is appalled by British racism and aggression for conquest. After her husband's death, she undertakes a continental journey, which helped her discover her stance in life. Her travels and exposure awakened her nationalist zeal for the 'mother country.' The new realization gave a purpose to her life. She joined the Indian Independence League while in New York and started working with Mahatma Gandhi. Then she encourages Arjun's recruitment in the Indian Independence League. Uma shares with him, Gandhi's belief that the country can only benefit from having men of conscience in the army. Uma, in her conversation about the evils in Indian society such as casteism and untouchability with her nephew, Dinu, argues that these realities should not justify the existence of the colonizers.

By drawing a comparison between Indian and Burmese society, she convinces Dinu what the colonialists have made them believe is absolute deceit:

It is true that India is rich with evils like caste system, untouchability, widow burning, etc. But take the example of our own country, Burma, they had no caste system. On the contrary, the Burmese were very egalitarian. Women had high standing-probably more so than in the West. There was universal literacy. But Burma was conquered too, and subjugated... It is simply mistaken to imagine that colonialists sit down and ponder the rights and wrongs of the societies they want to conquer: that is not why empires are built. (TGP 294-95)

The British Indian soldiers who once were trusted servants of the Empire and joined the army out of aspiration of being called 'Sahibs,' ultimately, become conscious of their condition. Arjun, for instance, used to consider soldiering just a career; however, now the word has the 'sting of an insult' for him. Ghosh, satires this assumption reflectively, 'Was it because soldiering was not just a job after all, as he had taught himself to believe? That to kill without conviction violated some deep and unalterable human impulse?'(TGP 347). Eventually, Hardy and Arjun regretted their contribution to the army despite their earlier belief on the idea that the 'British stand for freedom and equality.' Hardy 
reflects profoundly on the British Indian Army that despite being a majority, they hardly get the credit of wining battles, which often goes to Australians or Canadians or British. He remarks 'whether you won or lost, neither the blame nor the credit would be yours'; thus, he questions 'who is this weapon aimed at? Am I going to risk my life for this?' (TGP 40607). Hardy also confides this dilemma to Arjun:

When I was sitting in that trench, it was as if my heart and my hand had no connection -each seemed to belong to a different person. It was as if I wasn't a human being -just a tool, an instrument. This is what I ask myself Arjun in what way do I become human again? How do I connect what I do with what I want in my heart? (TGP 407)

The same new consciousness and realization have forced more than half of the fifty-five thousand British Indian soldiers to join the Indian National Army when Singapore fell. Most of these were Tamil plantation workers in Malaya. These were one of the many Indian groups considered racially unfit for soldiering. Arjun and his Indian professional soldiers who once were steeped into this racial mythology now recognize how false those myths were. They now rid themselves of old imperial notions of who made good soldiers and who didn't. The plantation recruits also proved to be equally dedicated as professional soldiers. After the Plantation soldiers flooded to the Indian National Army, many professional armies now realized the people they were fighting against turned out to be their relatives and neighbors.

Therefore, Ghosh portrays the historical awakening and resistance of the Indians to the British Empire in The Glass Palace. The gradual consciousness about exploitation and the awakening of the colonized to resist colonizers after the initial illusion is a phenomenon of colonized societies in both the novels.

\section{Conclusion}

I have found the two novels under my analysis as efforts to resist the dominant narratives. Moreover, the novels account for the atrocities of the empire and the ways it shaped their countries and societies against colonialism's legitimization by the west.

The Conscript and The Glass Palace, despite being productions of differing colonial experiences (Italian and British respectively) and geographical spaces, both depict similar motives of colonization, expansion strategies, and tropes of interiorizing the natives. This is truly illuminating as it reiterates what V.G. Kiernan calls empires imitating one another. Like most postcolonial writings, the novels delineate the asymmetrical power relationship between the colonizers and the colonized based on racial discrimination, perpetration of injustice, and concomitant resistance by the colonized. The novels are also, in a way, attempts to refute the colonizing world's self-assumed role as emissaries of God to civilize the colonized world.

Though Hailu and Ghosh deal with similar experiences and intentions in their works, they have slightly notable differences as well. Hailu wrote his novel when colonialism was still a reality of life in his life. He thus partly has included his lived experience consciously in fulfilling his role of 'generational mission' as Fanon calls it. The political and cultural decolonization he envisages in his work was at his own life's risk. Therefore, by accounting and responding to colonialism, he anticipates the mid-twentieth century colonial critics such as Frantz Fanon and Aime Cesaire. Ghosh, on the other hand, has composed his novel by looking back and imagining what his people must have gone through. However, his novel has striking thematic semblance with Hailu's, The Conscript, a work written back in the days of colonialism.

This comparative postcolonial analysis of the two novels has attempted to note and trace the thematic depictions in the two narratives. Firstly both the novels account for native soldiers' role and complicity in expanding and building the empires. The collaboration of Eritrean soldiers with their Italian masters in an invasion of Libya and the role of British Indian sepoys in expanding the British empire to Burma and other South East Asian countries is one marked comparison in the novels. Similarly, the novels paint graphically the atrocities and violence perpetrated by the colonizers and its impacts.

Furthermore, the novels account for the ultimate awakening and anticolonial sentiments that rose in their societies after the frustrations they have been through. The novels assume a combative narrative 
strategy in an attempt to undo the political and ideological colonization. This demonstrates to us, postcolonial readers, colonialism because of its incongruity and atrocities that can never last long, and the colonized are bound to realize its brutality and injustice and fight it back.

\section{References}

Ashcroft, Bill, et al. The Empire Writes Back: Theory and Practice in Post-Colonial Literature. Routledge, 2006.

Fanon, Franz. The Wretched of the Earth. Penguin, 1965.

Ghosh, Amitav. The Glass Palace. Harper Collins Publishers, 2017.

Hailu, Ghebresus. The Conscript: A Novel of Libya's Anticolonial War, translated by Negash,
Ghirmai, Ohio University Press, 1950.

Nandy, Ashis. The Intimate Enemy. Oxford University Press, 1983.

Nursey-Bray, Paul. "Race and Nation: Ideology in the Thought of Frantz Fanon." The Journal of Modern African Studies, vol. 18, no. 1, 1980, pp. 135-142.

Parker, Michael, and Roger Starkey. Postcolonial Literatures. Macimillan Press Ltd., 1995.

Said, E.W. Culture and Imperialism. Vintage Books, 1994.

Said, E.W. Orientalism: Western Conceptions of the Orient. Penguin Books, 1978.

Said, E.W. Representation of the Intellectual. Vintage Books, 1994.

Young, Robert J. C. "The Postcolonial Comparative." PMLA, vol. 128, no. 3, 2013, pp. 683-689.

\section{Author Details}

Mahder Reka, Assistant Lecturer, Department of English, College of Education, Eritrea Institute of Technology, Eritrea, Horn of Africa, (Part II MA English, Goa University, Goa, India), Email ID: mahderreka@gmail.com. 